\title{
River waters near to agricultural sites in the Northeastern Brazil (Maranhão State) cause genetic damage in Nile Tilapia (Oreochromis niloticus)
}

\author{
M. S. Castro ${ }^{a, b}$, R. Luvizotto-Santos ${ }^{b, c}$, S. R. F. Pereira ${ }^{a}$, V. R. Moreira ${ }^{a}$, P. V. Castelo-Branco ${ }^{a}$, \\ V. L. M. Silva and L. F. Carvalho-Costa ${ }^{a *}$
}

\begin{abstract}
aDepartamento de Biologia, Universidade Federal do Maranhão - UFMA, Cidade Universitária Dom Delgado, Avenida dos Portugueses, 1966, Bacanga, CEP 65080-805, São Luis, MA, Brasil

bPrograma de Pós-graduação em Biodiversidade e Conservação, Universidade Federal do Maranhão - UFMA, Cidade Universitária Dom Delgado, Avenida dos Portugueses, Bacanga, 1966, CEP 65080-805, São Luis, MA, Brasil

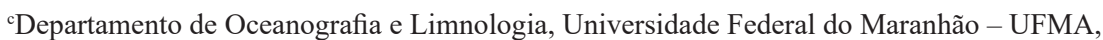
Cidade Universitária Dom Delgado, Avenida dos Portugueses, 1966, Bacanga, CEP 65080-805, São Luis, MA, Brasil

${ }^{\mathrm{d}}$ Departamento de Química e Biologia, Universidade Estadual do Maranhão - UEMA,

Cidade Universitária Paulo VI, Tirirical, CP 09, CEP 65055-970, São Luis, MA, Brasil

*e-mail:1fcc@ufma.br
\end{abstract}

Received: August 22, 2017 - Accepted: October 2, 2017 - Distributed: May 31, 2019

(With 2 figures)

Munim River is a small basin $\left(15,918.04 \mathrm{~km}^{2}\right.$, 320,000 inhabitants) in northeastern Brazil (Maranhão state), whose water quality has been threatened by pesticides, untreated domestic and industrial wastewater discharges, and solid waste disposal (Presoti and Cutrim, 2011). These pollutants may bring several problems to the aquatic biota, such as mutagenic and carcinogenic effects (Bolognesi and Hayashi, 2011) including risks to human health. Therefore, it is critical to understand the potential impacts of xenobiotics on this river basin, especially their genotoxic and mutagenic effects. We investigated the genotoxic and mutagenic potential of the Munim River waters to assess the impact of the presence of xenobiotics on the aquatic biota.

We collected water from two sampling sites (Figure 1) in September 2015 (dry season). As test organism, we used 40 juvenile Nile tilapia (Oreochromis niloticus) obtained from local fish farms, which were acclimatized to experimental conditions for 30 days in a 1,000-L (Liter) tank and maintained with constant filtration and aeration system. Fish were fed three times a day with commercial fish food at a proportion of $5 \%$ of their biomass. Four $80-\mathrm{L}$ water glass tanks containing ten fish each were used, as follows: a) negative control (tap water from a well); b) positive control (intraperitoneal injection of cyclophosphamide at $50 \mathrm{mg} / \mathrm{kg}$ ); c) Water from Sampling site 1; and d) Water from Sampling site 2. Fish were exposed to treatments for 72 hours without the provision of food in a static system with constant aeration (Ethics Committee Permit: CEUA \# 23115.008075/2016-12).

We measured genotoxic and mutagenic effects of water samples on the erythrocytes from tilapias using the comet assay (Singh et al., 1988; Tice et al., 2000) and the micronucleus test (Hooftman and Raat, 1982), respectively. For comet assay, we acquired the damage scores by observing the number of nucleoids in each damage class ( 0 to IV) per sample under fluorescence microscopy. The damage score was calculated by multiplying the number of nucleoids in each class by the respective class value according to Speit and Hartmann (1995). DNA damage scores revealed a normal distribution (Shapiro-Wilk test) and were analyzed by ANOVA (analysis of variance) followed by Tukey test $(p<0.05)$. The frequency of micronuclei was determined by observing 1000 cells per sample under light microscope. Because data did not fit into normal distribution, we applied the Kruskal-Wallis test, followed by Student-Newman-Keuls test $(\mathrm{p}<0.05)$.

Water from both sampling sites proved to be genotoxic and mutagenic to $O$. niloticus. Cells showed high DNA damage, showing high genotoxicity (Figure 2A), similar to the positive control $(\mathrm{p}<0.05)$. We also found a significant increase in the frequency of micronuclei when all groups are compared to the negative control $(\mathrm{p}<0.05)$ (Figure $2 \mathrm{~B}$ ).

Sampling sites are $181 \mathrm{~km}$ apart and showed the same level of DNA damage and mutagenic effects, revealing that harzadous xenobiotics are widely dispersed along the basin. Both sites are located in a region characterized by small subsistence agriculture and discharge of untreated sewage. The city of Chapadinha (Sample site 1) and others regions from Middle-Upper Munim drainage are also affected by large scale transgenic soybean cultures (Presoti and Cutrim, 2011) dependent on the use of the glyphosate herbicid, which has been shown to be genotoxic and mutagenic to fish, even at low concentrations (Moreno et al., 2014). Other studies have showed that several compounds, even in small concentrations, may be associated with genotoxicity and mutagenicity on aquatic organisms (Barberio et al., 2009). Some compounds, such as surfactants, phenols, and metals, together with untreated domestic and industrial wastewater discharges are also associated to genotoxic and mutagenic effects in fishes and might be present in the Munim waters (Steffens et al., 2015). 


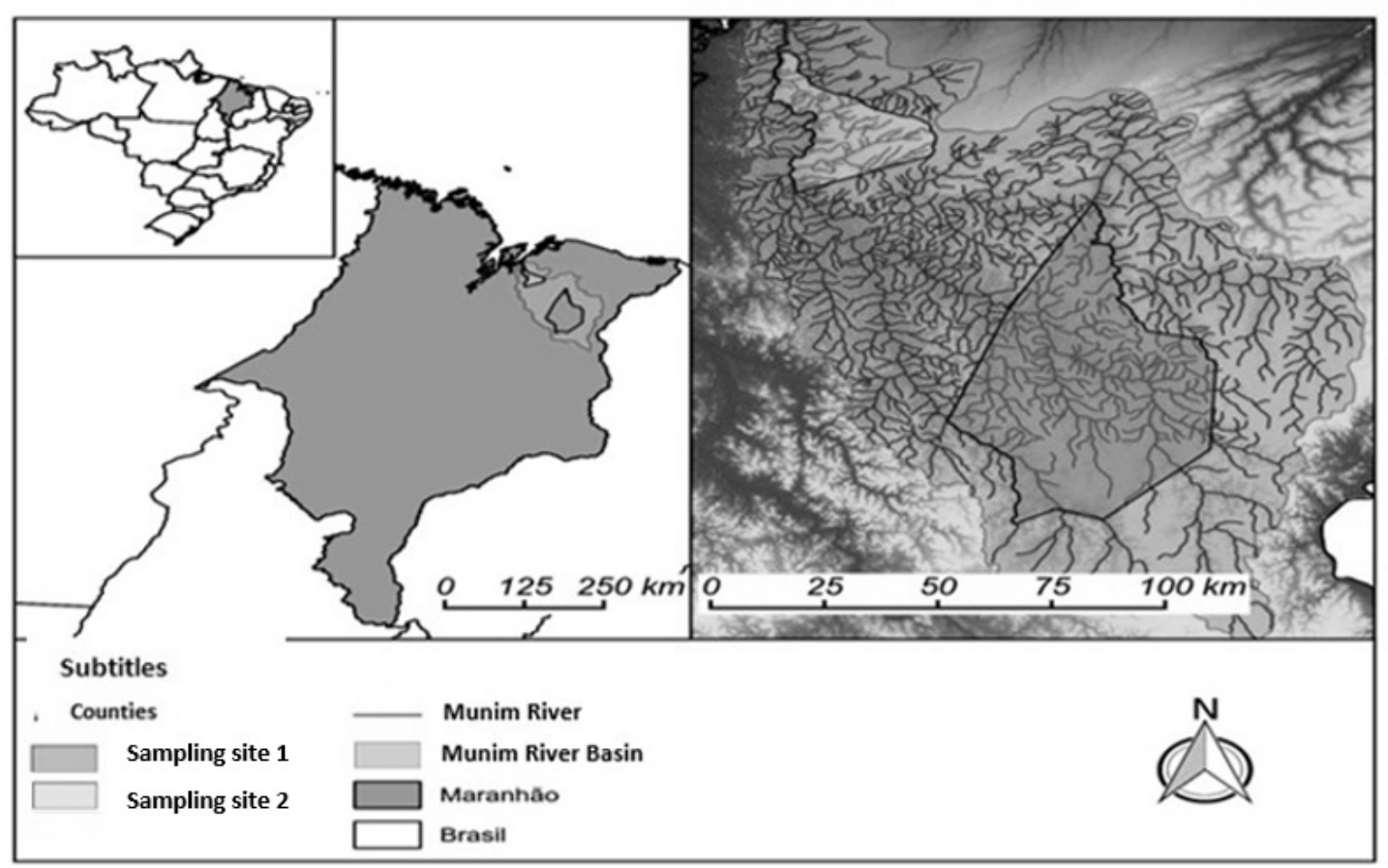

Figure 1. Location of Munim River Basin, in Maranhão State, and cities where water samples were collected. Sampling

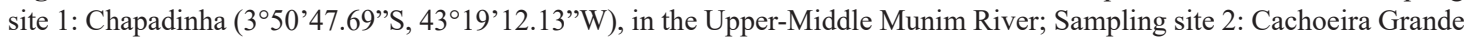
(3॰8’30.16”'S, 4354'19.86”W), in the Lower Munim River.

A
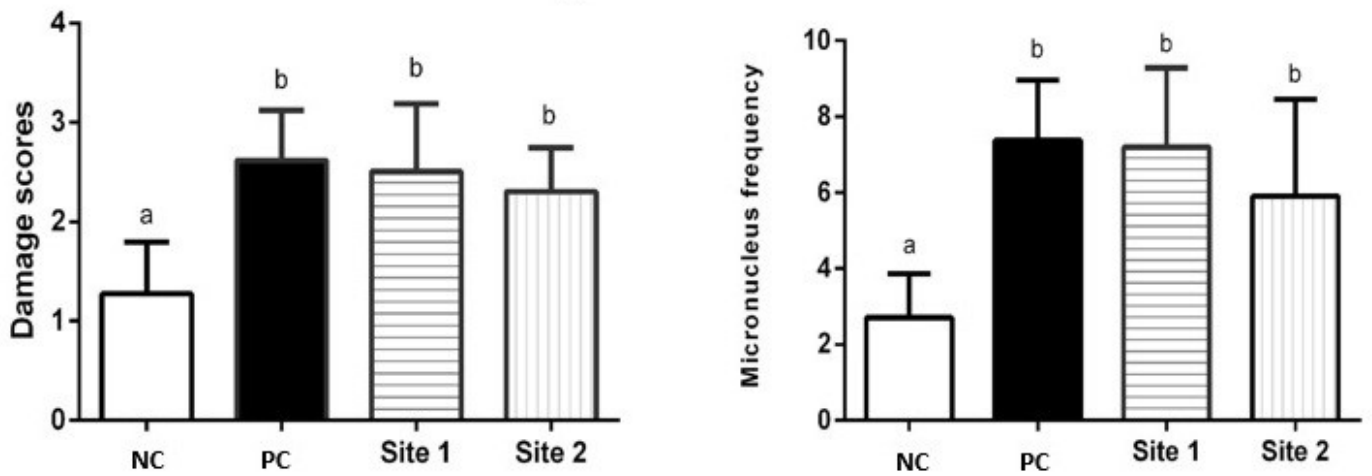

Figure 2. (A) Scores of DNA damage measured by the comet assay on erythrocytes of $O$. niloticus exposed to water samples from the Munim River for $72 \mathrm{~h}$. Different letters indicate statistically significant differences between groups; (B) Frequency of micronuclei in erythrocytes of $O$. niloticus exposed to water samples from the Munim River for $72 \mathrm{~h}$. Different letters indicate statistically significant differences between groups. NC: Negative Control (well water); PC: Positive Control (Cyclophosphamide at $50 \mathrm{mg} / \mathrm{kg}$ ); Sampling site 1: Chapadinha; Sampling site 2: Cachoeira Grande.

This is the first time that genotoxic and mutagenic effects of waters from the Munim River are demonstrated. Our results suggest the presence of xenobiotic agents affecting the DNA of the aquatic biota. We emphasize that many other neotropical river basins, like Munim, are exposed to similar anthropogenic activities, thus we suggest the need for monitoring water quality (and sediment) in order to identify xenobiotics and its impacts on the biota, as well as on human populations who utilizes these hydric resources.

\section{References}

BARBÉRIO, A., BARROS, L., VOLTOLINI, J.C. and MELLO, M.L.S., 2009. Evaluation of the cytotoxic and genotoxic potential of water from the River Paraíba do Sul, in Brazil, with the Allium 
cepa L. test. 2009. Brazilian Journal of Biology $=$ Revista Brasileira de Biologia, vol. 69, no. 3, pp. 837-842. http://dx.doi.org/10.1590/ S1519-69842009000400010. PMid:19802442.

BOLOGNESI, C. and HAYASHI, M., 2011. Micronucleus assay in aquatic animals. Mutagenesis, vol. 26, no. 1, pp. 205-213. http:// dx.doi.org/10.1093/mutage/geq073. PMid:21164204.

HOOFTMAN, R.N. and RAAT, W.K., 1982. Induction of nuclear anomalies (micronuclei) in the peripheral blood erythrocytes of the eastern mudminnow Umbra pygmaea by ethyl methanesulphonate. Mutation Research, vol. 104, no. 1-3, pp. 147-152. http://dx.doi. org/10.1016/0165-7992(82)90136-1. PMid:7078568.

MORENO, N.C., SOFIA, S.H. and MARTINEZ, C.B.R., 2014. Genotoxic effects of the herbicide Roundup Transorb and its active ingredient glyphosate on the fish Prochilodus lineatus. Environmental Toxicology and Pharmacology, vol. 37, no. 1, pp. 448-454. http://dx.doi.org/10.1016/j.etap.2013.12.012. PMid:24448465.

PRESOTI, A.E.P. and CUTRIM, M.V.J., 2011. Environmental impacts of soybean plantation in an aquatic ecosystem of the microregion Chapadinha, Maranhão - Brazil. In: C. BILIBIO, O. HENSEL and J. SELBACH, eds. Sustainable water management in the tropics and subtropics: and case studies in Brazil. Jaguarão: Fundação Universidade Federal do Pampa, vol. 1, 1358 p.
SPEIT, G. and HARTMANN, A., 1995. The contribuition of excision repair to the DNA repair to DNA effects seen in the alkaline single cell gel test (comet assay). Mutagenesis, vol. 10, no. 6, pp. 555-559. http://dx.doi.org/10.1093/mutage/10.6.555. PMid:8596477.

STEFFENS, C., KLAUCK, C.R., BENVENUTI, T., SILVA, L.B. and RODRIGUES, M.A.S., 2015. Water quality assessment of the Sinos River - RS, Brazil. Brazilian Journal of Biology = Revista Brasileira de Biologia, vol. 75, no. 4, suppl. 2, pp. 62-67. http://dx.doi.org/10.1590/1519-6984.01613suppl. PMid:26628228.

SINGH, N.P., MCCOY, M.T., TICE, R.R. and SCHNEIDER, E.L., 1988. A simple technique for quantification of low levels of DNA damage in individual cells. Experimental Cell Research, vol. 175, no. 1, pp. 184-191. http://dx.doi.org/10.1016/00144827(88)90265-0. PMid:3345800.

TICE, R.R., AGURELL, E., ANDERSON, D., BURLINSON, B., HARTMANN, A., KOBAYASHI, H., MIYAMAE, Y., ROJAS, E., RYU, J.C. and SASAKI, Y.F., 2000. Single cell gel/ comet assay: guidelines for in vitro and in vivo genetic toxicology testing. Environmental and Molecular Mutagenesis, vol. 35, no. 3, pp. 206-221. http://dx.doi.org/10.1002/(SICI)10982280(2000)35:3<206::AID-EM8>3.0.CO;2-J. PMid:10737956. 